\title{
Describing to Improvement of Students' Skill in Relief Print by Using Explicit Instruction
}

\author{
Harni $^{\mathrm{a}}$ \\ a Padang State University, Padang, Indonesia \\ Corresponding e-mail: harni@yahoo.com
}

\begin{abstract}
This research was aimed at describing the improvement of students' skill in relief print by using explicit instruction in second grade of elementary school. This was a classroom action research which applied qualitative and quantitative approaches. The subject of this research was the practitioner teacher and 28 students in the second grade. The result of the research indicated that lessons plans get 78,5\% into 92,5\% and teacher ability from $74 \%$ into $92,5 \%$ in second cycle. Students ability get $65,5 \%$ to $90,5 \%$ in second cycle. The students' ability in relief print improved from 65,39 (adequate) in first cycle into 80,67 (good) in the second cycle.
\end{abstract}

Keywords: Describing, Relief and Explicit Instruction

\section{INTRODUCTION}

Art education in elementary is aimed to develop and foster students' thinking ability. Art will encourage students to develop their creativity, to achieve intellectual intelligence, emotional intelligence, motoric intelligence. Sumanto (2006: 19) believes that "the role of art is to develop Students' thinking ability, creativity, sensitivity senses and art skills". Considering the importance role of art education in elementary school, it is necessary to develop elementary school students' art learning process to develop creativity and skill to express ideas through art.

Learning art is one way to develop students' creativity in expressing their ideas. Embossed printing techniques is of subjects that is taught in $2^{\text {nd }}$ grade of primary school in second semester. Students are expected to express their idea through this technique. Cultural Arts and Skills Learning will become knowledge, creativity, and medium to teach students with attitudes and values. Teachers are asked to develop learning activities that foster student creativity and motivation.

Based on observations that researchers conducted on October 28 and November 1 in $2^{\text {nd }}$ grade of elementary school students of SD Negeri 10 Sapiran, Bukittinggi city, there are several problems in teaching and learning activity. the problems are (1) teachers do not use various kinds of sources in making the lesson plan, (2) the common method that is used is demonstration, (3) the advance training is out of teachers' guidance (5) there is no evaluation to how far student develop their skills in embossed printing. This conditions led to (1) students' knowledge of printing theory will be very superficial, (2) students' understanding of printing skills will be very low, and do not understand the steps of printing, (3) generally the task will be completed by Parents, siblings or people deemed skilled in printing techniques, (4) besides that the only assessment that can be done is the result assessment, whereas the assessment of the process at the time of making the skill has its own value (5) all the work of the students will be displayed in the classroom. Students who work it by himself will be not confidence with their work.

Based on the background that has been stated above, the research problem in general is how to improv students printing skills with direct learning model second grade students of SD Negeri 10 Sapiran, Bukittinggi?. The detail of the research problems are described as follows: 1) How is the lesson plan to improve the skills of printing with direct learning model?, 2) How is the implementation of the lesson plan in teaching students embossed printing with direct learning model?, 3) To what extend with direct learning model can develop students' embossed printing skills? 


\section{METHODOLOGY}

The type of this research is Classroom Action Research with qualitative and quantitative approach. The subjects of the study was the second grade students of SD Negeri 10 Sapiran, consisting of 28 students. There are 13 male students and 15 female students. This study was conducted in two cycles. The first cycle was held on Tuesday, April 19, 2016 and Friday, April 22, 2016 and cycle II was held on Wednesday, April 27, 2016 and Saturday, April 30, 2016.

Research data is data obtained by researchers during the research in the form of observations of every action improvement of high print skill learning by using direct learning model in class II SD Negeri 10 Sapiran, Bukittinggi. The data is related to the planning, implementation, and learning outcomes in the form of information as follows: 1) Planning of the implementation of learning activities to achieve the learning objectives. 2) Implementation of learning related to the behavior of teachers and students that include the interaction of teaching and learning between teachers and students, fellow students, and student-teachers in learning. 3) Assessment of learning skills of printing by using direct learning model. Assessment includes the process of workmanship and the results (products) work of students.

Data collection techniques used were observation and scoring learning scores (process and outcome). While the instrument used is an observation sheet and assessment sheet (process and results). Kunandar (2008: 123) states that the data analysis techniques used in this classroom action research derived from two types of data, namely qualitative and quantitative. The data collected in each observation activity on the implementation of classroom action research cycle is analyzed descriptively by using percentage technique to see the tendency that happened in the learning activity. The data is reduced based on the problem under study, followed by the presentation of data and the last conclusion or verification. Such an analysis stage is repeated once the data is collected at each stage of data collection in each action.

\section{RESULTS}

\subsection{Cycle I}

The use of direct instructional models in print skill learning is started by designing the lesson plan by considering the elementary school curriculum a planning. The cycle I will discuss about theory of printing using the midrib and practicing it. The standard of competence is expressing themselves through art and the basic competence that must be mastered by students is Expressing themselves through embossed printing techniques. there are several indicators of this basic competence. the indicators are: 1) Identify the types of printing, 2) Identify the types of tools and materials that can be used to make embossed printing cliché, 3) Identify the print motifs of various midribs, 4) Describe the print steps using the midrib, 5) practice print from the midrib. The researcher also prepares: 1) observation sheet of the implementation plan of learning skill of printing using direct learning model, 2) observation sheet of teacher activity in learning of print skill using direct learning model, 3) observation sheet of student activity in learning of print skill using direct learning model, 4) Preparing process assessment sheets and student work. The assessment undertaken in this lesson is a process assessment and outcome assessment. Process assessment includes aspects of seriousness in printing, the smooth use of tools and materials, as well as the suitability of the printing steps. Assessment of results that includes aspects of neatness, composition, and the creation of a stamp / mold. Implementation of the learning of print skills using the direct learning model was developed based on the steps according to Joyce and Weil (in Ridwan, 2014: 125, that is: 1) learning orientation, 2) presentation of materials, 3) structured training, 4) Self-training. The implementation of lesson plan in first cycle is implemented in two meetings, with a time allocation of $4 \times 35$ minutes. There are three stages activities in Implementation processes. the stages are initial activities, core activities, and end activities.

\subsubsection{Initial Activity}

At the initial activity, teacher prepares class to a conducive learning environment. Teacher checks the attendance of the students. Teacher greets students with friendly and students answered simultaneously. Teacher motivates students by asking them with the students ever put his wet hands to the wall, then associated with the material to be studied.

\subsubsection{Core Activities}

At the beginning of the core activities the teacher presents the material about embossed printing by using a midrib. The next phase is assigning students to practice doing the embossed printing as demonstration before. In the guiding stage of the training, teachers guide students in work and provide assistance to students who are still hesitant in working. The last stage is madiri training, at this 
stage students are assigned to train to create print works independently without the help of teachers.

\subsubsection{Final Activities}

In the final activity, teacher asks the students to conclude the lesson about what there are during along the learning processes.

Based on observation, the percentage of lesson plan assessment that has been prepared by teachers in the first cycle of meeting is $75 \%$ with sufficient qualification. This deficiency was corrected at the second meeting and increased to $82 \%$ with good qualification. The average percentage of the effectiveness of lesson plan in cycle I is 78,5\%. Percentage of teacher activity in meeting is $71 \%$ with enough qualification. This deficiency was corrected at the second meeting and increased to $78 \%$ with excellent qualifications. The average percentage of teacher activity assessment in cycle I is $74.5 \%$. Percentage of student activity appraisal obtained at cycle I in the first meeting is $60 \%$ with enough qualification. This deficiency was corrected at the second meeting and increased to $71 \%$ with sufficient qualification. The average percentage of students' activity assessment in cycle I is $65.5 \%$. Results of the students' skills gradually increased from cycle I to cycle II, the average assessment in the first cycle of meeting I was 61.15 and then increased at the second meeting that is 70.5 . The average of student skill score on cycle I is 65,39 .

The overview percentage of cycle I

\begin{tabular}{|l|l|l|l|l|}
\hline \multirow{2}{*}{ No } & \multirow{2}{*}{ Observed aspects } & \multicolumn{3}{|c|}{ Siklus I } \\
\cline { 3 - 5 } & First & $\begin{array}{l}\text { Pertemu } \\
\text { an II }\end{array}$ & $\begin{array}{l}\text { Rata- } \\
\text { Rata }\end{array}$ \\
\hline 1 & Lesson plan & $75 \%$ & $82 \%$ & $78,5 \%$ \\
\hline 2 & Teacher aspect & $71 \%$ & $78 \%$ & $74,5 \%$ \\
\hline 3 & Student aspect & 60, & $71 \%$ & $65,5 \%$ \\
\hline 4 & $\begin{array}{l}\text { Skill or learning } \\
\text { outcome }\end{array}$ & 61,15 & 70,5 & 65,39 \\
\hline
\end{tabular}

Reflection is done collaboratively between researchers with observers at the end of learning. Reflection on this cycle I includes reflection of designing lesson plan, reflection of action implementation, and reflection of skill result assessment. Based on the results of observation shows that the implementation of printed skills learning by using direct learning model has not been implemented properly in accordance with the steps listed in the RPP. It is necessary to plan the implementation of the action in the next cycle by focusing on improvements to any deficiencies and constraints encountered during the first cycle action, which are used as material improvements for cycle II.

\subsection{Cycle II}

Action performed on cycle II is based on the results of reflection conducted on cycle I. In the second cycle, the implementation of the action is done in 2 meetings. The first meeting was held with $2 \times 35$ minutes for the material on Wednesday April 27, 2016 and the second meeting was held on Saturday 30 April 2016 with $2 \times 35$ minutes. The result of cycle II will be described as follows: learning cycle II is about making prints using foliage and making printed works using tubers. Standard Competence is expressing itself through art. The basic competence is that students can express themselves through embossed printing techniques. The indicator 1) make the print works using leaves, 2) make the work using the midrib. Improved printing skills using direct learning models are developed based on the steps according to Joyce and Weil.

\subsubsection{Initial Activity}

At the initial activity, teacher prepares class to a conducive learning environment. Teacher checks the attendance of the students. Teacher greets students with friendly and students answered simultaneously. Teacher motivates students by asking them with the students ever put his wet hands to the wall, then associated with the material to be studied.

\subsubsection{Core Activities}

At the beginning of the core activities the teacher begins by presenting the material by displaying the printed images using leaves and tubers, followed by demonstrating the stages of printing using leaves and tubers. Material presentation activities are accompanied by structured exercises, where students work based on information conveyed by the teacher. The next stage is student practicing in make embossed printing. TEACHER guides students who are considered less skilled and still hesitant in working. the students are assigned to make the print works independently with their own creativity as the final stage.

\subsubsection{End Activities}

Teacher asks the students to conclude the lesson. Throughout the actions that have been done.

The percentage of lesson plan assessment that has been prepared by teachers in cycle II of first 
meeting I is $89 \%$ with very good qualification an it is improve in the second meeting increased to $96 \%$ with excellent qualification. The average of lesson plan in cycle II is $92,5 \%$. Percentage of teacher activity assessment in first meeting is $89 \%$ with very good qualification. Then at the second meeting increased to $96 \%$ with excellent qualification. The average percentage of teacher activity assessment in cycle II is $92.5 \%$. Percentage of student activity assessment obtained in cycle II of first meeting is $85 \%$ with good qualification. Then at the second meeting increased to $96 \%$ with excellent qualification. The average percentage of student activity assessment in cycle II is $90.5 \%$. The result of the students' skill has increased gradually from cycle I to cycle II, the average of assessment in cycle II of first meeting is 77,06 then it is increased at second meeting to 83,75 . The average of student skill score on cycle II is 80,67 .

The overview percentage of cycle II

\begin{tabular}{|l|l|l|l|l|}
\hline \multirow{2}{*}{ No } & \multirow{2}{*}{$\begin{array}{l}\text { Observed } \\
\text { aspect }\end{array}$} & \multicolumn{3}{|c|}{ Cycle II } \\
\cline { 3 - 5 } 1 & $\begin{array}{l}\text { Lesson } \\
\text { Plan }\end{array}$ & $89 \%$ & $96 \%$ & $92,5 \%$ \\
\hline 2 & $\begin{array}{l}\text { Teacher } \\
\text { aspect }\end{array}$ & $89 \%$ & $96 \%$ & $92,5 \%$ \\
\hline 3 & $\begin{array}{l}\text { Student } \\
\text { aspect }\end{array}$ & $85 \%$ & $96 \%$ & $90,5 \%$ \\
\hline 4 & $\begin{array}{l}\text { Learning } \\
\text { outcome } \\
\text { Skill) }\end{array}$ & 77,06 & 83,75 & 80,67 \\
\hline
\end{tabular}

The result of skill enhancement is obtained through process assessment and the resultant (product) assessment of the student has increased. In addition, students can achieve all the learning objectives. This indicates that direct learning model can improve students' skills in embossed printing.

Apart from these shortcomings, the implementation of print skill learning using the direct learning model in cycle II has been well qualified. Similarly, the assessment of teacher and student activity. thus, the learning cycles of classroom action research are only two cycle.

\section{DISCUSSION}

\subsection{Cycle I}

Implementation of research on the learning of print skills using direct learning model begins by preparing a learning design. The design of learning prepared by the researchers in the form of learning implementation plan as contained in the description of research results. The study consisted of two cycles, each cycle consisting of two learning implementation plans. In the first cycle of learning implementation plans both at meetings I and II are still found many drawbacks. The drawbacks include the clarity of the formulation of the objectives of the learning process, which is still not in accordance with the student environment. This shortcoming is in line with the opinion expressed by Lukman (2012: 110) "the formulation of objectives needs to be made more specifically so that it clearly describes the expected form of behavior and learning materials". The characteristics of these students concern the interests and talents of students in the development of the potential that exists in themselves. This is in line with the opinion of Hilda Taba (in Lukman 2012: 121) "learning materials have the importance of teaching material that is taught really needed students, besides learning materials should be learned and adapted to the student experience. In addition, the shortcomings found are time allocation not in accordance with the time available. This shortage occurs due to lack of teacher accuracy in estimating the time required. Masnur (2007: 46) states "The time division of each meeting hour is based on the learning objective unit or the nature / type / type of learning materials". Besides, the education units have not been listed and the formulated indicators have not been sequenced and not in accordance with the basic competencies. This shortcoming is increasingly apparent with the opinion of Susanto (2007: 157) which states "Each formulated indicator should be ensured to really indicate the basic competencies described and formulated in such a way that the level of achievement can be measured and observed."

Based on these data, the researcher tried to rearrange the implementation plan of learning for the learning activity of cycle II. As the results of observations obtained from the research that has been done then got percentage of success of each learning implementation plans. In the result of observation learning implementation plan's assessment in cycle I, the percentage for first meeting is $75 \%$ with sufficient qualification. However, the plan still needs improvement to obtain a more perfect percentage. Therefore, second meeting designed the learning activities that maximize the shortcomings from the first meeting. it is resulted in the improvement of the learning implementation plan percentage of $82 \%$ with good qualifications. However, the plan still needs improvement to get a better percentage.

Teacher activity success in the first cycle I is $71 \%$ meeting with sufficient qualifications. Furthermore, in the implementation of cycle I of 
meeting II, teachers provide more opportunities for students to learn actively. It does not contribute a significant increase of teacher activity. the score for teacher is with good qualification. Thus, the learning process should proceed to cycle II. Based on the exposure of the scoring results data of the scoring skills using the direct learning model of cycle I, the assessment of learning is the process assessment and the result assessment (product). The aspect observed in the process assessment is the sincerity in printing, the smoothness of using tools and the suitability of the steps. While the assessment of the results (products) include aspects of neatness, composition and stamp creations.

on the other hand, student learning outcome average is 61.15 in the first meeting. the improvement in the meeting II is still low which is is 70.5. So that the average score of student skill in learning skill of print using direct learning model in cycle I that is 65,39 . The results of the scoring improvement assessment with the direct learning model obtained during the implementation of cycle I have not reached the expected results so that the implementation should proceed to cycle II.

\subsection{Cycle II}

Planning cycle II is based on the results obtained from cycle I. After observed by the observer there are still some shortcomings in the RPP that researchers arrange. The disadvantage is that in the planning of meeting action I there is little deficiency that the material is not in accordance with the latest developments in the field and the source is not in accordance with the development and environment of students, whereas at the second meeting found improvement where there is only a lack of aspects of learning resources that have not been in accordance with the development environment Students. Learning materials and resources are important aspects to consider before beginning learning. This is an important element for achieving defined learning objectives. Media and learning resources are references that are able to provide learning in the classroom. Learning resources can be books, internet, experts or figures, places or specific locations. Harjanto (2006: 224) states "learning materials are sourced from a standard source book, an expert personal teacher, and community". Such a thing is necessary in the learning process because learners will learn and keep learning if the learning conditions are made fun. The atmosphere of a fun learning process is necessary because the brain will not work optimally when the feeling is depressed. Feelings of pleasure will arise when the learning process using a variety of interesting sources. As the results of observations obtained from the research that has been done then got percentage of success of each learning implementation plan. In the result of observation learning implementation plan cycle II meeting I is $89 \%$ with very good qualification and on result of observation learning implementation plan cycle II meeting II is $96 \%$ with very good qualification.

Implementation of learning in cycle II is almost the same as the learning in cycle I. The difference lies in the materials used for printing. Where in cycle II materials used are foliage and tubers. The learning phase in cycle II is the same as the step of the direct learning model in cycle I. In the second cycle of the student implementation can complete the assigned task well. In the learning process students are no longer embarrassed in giving their opinions, students want to ask about the difficulties they face and students are also more motivated in learning because of the strengthening given by teachers.

The success of this learning activity proves the learning that researchers have done successfully. From analysis of research cycle II, teacher activity in print skill learning have maximal. In the implementation stage the percentage of success by teachers in cycle II of meeting I get $89 \%$ with good qualification. Furthermore, on the second cycle II implementation of success by teachers get $96 \%$ with excellent qualifications. Based on the above exposure can be concluded that in the case of the implementation of cycle II teachers have successfully used direct learning model to improve the $2^{\text {nd }}$ grade students printing skills of SD Negeri 10 Sapiran City Bukittinggi. So that the learning process is completed in cycle II without continuing to the next cycle. Result of observation scoring skill learning appraisal using direct learning model, average assessment on cycle II of meeting I that is 77,06 then increase at meeting II that is 83,75 . The average of student skill score on cycle II is 80,67 .

Based on the exposure of data learning outcomes described above, learning outcomes obtained on the implementation of learning skills print using direct learning model in cycle II has reached the expected target completeness, so that research is sufficient until the second cycle only. Thus, it can be concluded that the use of direct learning model successfully improves students' skills of in printing.

\section{CONCLUSIONS SUGGESTIONS}

Based on the description of research results and discussion can be concluded that the use of direct learning model can improve second grade students' skills of SD Negeri 10 Sapiran City of Bukittinggi in embossed printing. Based on the observation of 
percentage of lesson implementation plan assessment in cycle I obtained the average of lesson implementation plan assessment that is $78,5 \%$. Then in cycle II has shown an increase, it is seen from the average assessment of RPP obtained in cycle II of $92.5 \%$. While the aspects of teachers in the first cycle obtained an average percentage of success of $74.5 \%$. This deficiency is rectified so that the average percentage of teacher activity success in cycle II is $92,5 \%$. While on the students' activity assessment obtained in the first cycle is $65.5 \%$. In the student activity also increased from cycle I to cycle II. This is seen from the percentage of student activity obtained on the second cycle is $90.5 \%$. The students' skill also increased gradually from cycle I with the average score of 65,39 and cycle II with the average score 80,67 .

From the results of research that researchers obtain, the researcher suggests some suggestions that if it can provide input for improving the skills of students are: In the planning stage of learning should a teacher really pay attention to the components that are important in a learning implementation plan. In the implementation stage of learning should a teacher should really be able to master and conditioned his class to learn. It is very important to do so that students can spirit of learning, and goals to be achieved can be realized optimally.
Assessment done to find out whether the learning is successful or not is an important thing that cannot be abandoned. This should be considered by the teacher in determining the assessment of the learning carried out, where the teacher should be as creative as possible in determining the assessment.

\section{REFERENCES}

[1] Koesrini, A. N. Sumanto, 2006. Keragaan Hasil Beberapa Galur Harapan Kacang Tanah di Lahan Sulfat Masam dan Lahan Lebak dangkal. Bul. Agron.(34)(1), 11-18.

[2] Kunandar, S. P., \& Si, M. (2008). langkah mudah Penelitian Tindakan Kelas sebagai pengembangan profesi guru. Jakarta: PT. Raja Grafindo Perkasa.

[3] Lukman, R., \& Krajnc, M. (2012). Exploring Non-traditional Learning Methods in Virtual and Real-world Environments. Educational Technology \& Society, 15(1), 237-247.

[4] Masnur, M. (2007). KTSP Dasar Pemahaman dan Pengembangan. Jakarta: Bumi Aksara.

[5] Susanto, A. F. (2007). Teori hukum: mengingat, mengumpulkan, dan membuka kembali. PT Refika Aditama. 